\title{
PENGEMBANGAN MODEL TRANSPORTASI PENUMPANG ANTAR KOTA/KABUPATEN DI PROPINSI JAWA BARAT
}

\author{
I Made Suraharta ${ }^{1}$ \\ ${ }^{1)}$ Program Studi Perkereta-apian, Sekolah Tinggi Transportasi Darat \\ Jl. Raya Setu, Cibuntu-Cibitung, PO.BOX 153, 17001, Bekasi, Jawa Barat \\ email: made_suraharta@yahoo.com
}

\begin{abstract}
Transport models are crucial in the transportation planning process. Transport model is made by adjusting the needs and availability of data and capability models in representing the real conditions and the future. Transportation models commonly used in transportation planning mechanism is the sequential demand models, which include the trip generation, trip distribution, mode choice, and traffic assignment. This model is suitable to be applied to various situations study areas, especially areas of the city. For intercity regional planning needs, modeling the sequential demand can be simplified into a direct demand model, the record is not much involved in modeling mode. In this study, the authors tried to develop a model of a direct demand models to represent the pattern of movement of people with other modes of road in West Java. The proposed transport model is a function of population, GDP, total number of trip generation traffic zone, the total transportation costs (generalized cost). Model results show the validity of the development of significant and can be used as a travel demand model for transportation planning.
\end{abstract}

Keywords : four-phase transport model, the direct demand model, population, gross regional domistik products, the value of time, travel expenses

\begin{abstract}
Abstrak: Model transportasi merupakan hal yang krusial dalam proses perencanaan transportasi. Model transportasi dibuat dengan menyesuaikan kebutuhan dan ketersediaan data dan kapabilitas model dalam merepresentasi kondisi nyata dan masa yang akan datang. Model transportasi yang umum digunakan dalam mekanisme perencanaan transportasi adalah model empat tahap, yang meliputi bangkitan dan tarikan perjalanan, distribusi perjalanan, pemilihan moda, dan pembebanan lalu lintas. Model ini cocok diterapkan untuk berbagai situasi wilayah studi, terutama wilayah kota. Untuk kebutuhan perencanaan wilayah antarkota, pemodelan empat tahap dapat disederhanakan menjadi model langsung (direct demand model), dengan catatan tidak banyak moda yang terlibat dalam pemodelan. Pada penelitian ini, penulis mencoba mengembangkan model permintaan langsung untuk merepresentasikan pola pergerakan orang dengan moda jalan di Jawa Barat. Model transportasi yang diusulkan merupakan fungsi dari populasi penduduk, PDRB, jumlah total tarikan/bangkitan perjalanan zona lalu lintas, biaya transportasi total (generalized cost). Model hasil pengembangan menunjukkan validitas yang cukup signifikan dan dapat digunakan sebagai model permintaan perjalanan untuk melakukan perencanaan transportasi.
\end{abstract}

Kata kunci : model transportasi empat tahap, model permintaan langsung, populasi penduduk, produk domistik regional bruto, nilai waktu, biaya perjalanan.

Masyarakat yang memerlukan interaksi sosial akibat adanya kebutuhan atas komoditas atau jasa lain akan menimbulkan permintaan transportasi. Adapun faktor penting yang mempengaruhi jumlah permintaan perjalanan ke tempat tertentu adalah jenis-jenis kegiatan yang dapat dilakukan di tempat tersebut atau tingkat 
pencapaian tujuan perjalanan di tempat itu, biaya, karakteristik alat transportasi, jumlah orang pada tempat asal, penghasilan, kegiatan utama yang biasa dilakukan dan lain-lain. Pada penelitian ini, sebagai daerah kajian adalah di Propinsi Jawa Barat dimana pada wilayah ini telah terjadi hubungan kerja sama pembangunan nasional antar kota/kabupaten yang dapat mendorong peningkatan kondisi sosial ekonomi yang selanjutnya menimbulkan konsekuensi meningkatnya kebutuhan dan mobilitas masyarakat yang menggambarkan permintaan perjalanan, khususnya angkutan penumpang. Hal ini akan membutuhkan suatu pelayanan angkutan yang dapat mengakomodir kawasan pergerakan antar kabupaten. Sementara rumusan atau model matematis sebagai simplifikasi dari fenomena yang ada, yang mampu memberikan gambaran kuantitatif pola kebutuhan pergerakan dan faktor-faktor yang berpengaruh terhadap kebutuhan transportasi penumpang, masih belum banyak dikembangkan.

Berdasarkan hal tersebut di atas, penelitian ini akan mencoba mengembangkan model untuk analisis terhadap kebutuhan/permintaan angkutan penumpang yang ada, walaupun pengembangan model itu sendiri kemungkinan akan banyak menghadapi kendala, akibat tingginya tingkat keberagaman dan kompleksitas variabel, serta keterbatasan data yang digunakan dalam model. Hasil pemodelan ini selanjutnya dapat digunakan sebagai salah satu alat bantu perencanaan transportasi di Propinsi Jawa
Barat. Model tersebut diharapkan dapat diterapkan untuk mengevaluasi pengaruh dari kebijakan dalam sistem transportasi atau untuk meramalkan kebutuhan transportasi pada masa yang akan datang. Bagaimanapun juga perencanaan dan pemodelan transportasi telah terbukti kegunaan dan peranannya dalam mengantisipasi permasalahan transportasi di masa yang akan datang.

Berkaitan dengan identifikasi kebutuhan pergerakkan, pola kebijakan transportasi yang dilakukan cenderung mengabaikan proses pemilihan model yang tepat, dimana model transportasi untuk setiap daerah bersifat eksklusif, yang dipenguruhi oleh karakteristik kondisi ekonomi dan atribut pelayanan jasa transportasi. Oleh karena itu, proses perencanaan dan pemodelan akan dapat digunakan sebagai alat bantu transportasi dalam pengambilan keputusan dan kebijakan jika sudah mempertimbangkan karakteritik wilayah tersebut.

Untuk memperjelas masalah yang dikenali sebelumnya, berikut ini diberikan perumusan masalah sebagai berikut:

- Bagaimana karakteristik permintaan dan sediaan angkutan penumpang di Propinsi Jawa Barat.

- Variabel apa saja yang berpengaruh terhadap kebutuhan pergerakan angkutan penumpang di Propinsi Jawa Barat.

- Bagaimana model kebutuhan pergerakan yang diusulkan dapat merepresentasikan pergerakan angkutan penumpang di Propinsi Jawa Barat. 


\section{KAJIAN PUSTAKA}

Adapun teori-teori yang melandasi penelitian ini dapat diiuraikan sebagaimana dibawah.

\section{Pengertian Model}

Tamin (1997 dan 2000) mendefinisikan model sebagai alat bantu atau media yang dapat digunakan untuk mencerminkan dan menyederhanakan suatu realita secara terukur, dan pada penelitian ini akan digunakan model statistik dan matematik yang dapat menerangkan secara terukur beberapa aspek fisik, sosial ekonomi, atau model transportasi. Sedangkan Ortuzar \& Willumsen (1994) mengemukakan definisi model sebagai suatu penampilan yang disederhanakan dari suatu realitas (sistem yang diteliti) yang berkonsentrasi hanya pada elemen-elemen tertentu yang dipentingkan.

Berkaitan dengan tipe model yang dipilih, Black (1981) berpendapat bahwa salah satu alasan penggunaan model matematik adalah karena matematik:

“... is more precise language among others. The precision required to translate words into symbols can often reveal inadequacies in the verbal description ... "

Keuntungan model matematis adalah pada saat pembuatan formulasi, kalibrasi model serta penggunaannya, perencana dapat melakukan eksplorasi rancangan model melalui eksperimen-eksperimen tentang kelakuan dan mekanisme internal dari sistem yang sedang dianalisis (Tamin, 2000).

\section{Karakteristik Angkutan Penumpang}

Dalam aktivitas perangkutan penumpang/orang, karakteristik yang terjadi berkaitan erat dengan interaksi antara penumpang dengan atribut pelayanan transportasi. Sebagai contoh, penumpang yang berbisnis biasanya lebih menghargai waktu perjalanan daripada penumpang yang mengunjungi teman. Penumpang dengan maksud perjalanan bisnis elastis terhadap waktu perjalanan tetapi sedikit elastis terhadap biaya perjalanan. Aspek dalam karakteristik perjalanan antar kota berbeda pada konteks perjalanan dalam kota. Aspekaspek tersebut antara lain set pilihan perjalanan, maksud perjalanan, jarak perjalanan, moda yang digunakan serta variasi arus lalu lintas yang terjadi.

\section{Analisis Kebutuhan Angkutan}

Secara umum terdapat 3 (tiga) pendekatan dalam analisis kebutuhan transportasi (Kanafani, 1983), salah satunya adalah pendekatan interaksi sosial. Pendekatan ini melihat daerah/zona-zona yang memiliki surplus (bangkitan) dan defisit (tarikan) perjalanan tertentu, terletak di berbagai titik yang terdistribusi dalam ruang, dan kemudian suatu proses interaksi diteorikan dengan anggapan bahwa pergerakan penumpang akan terjadi dari titiktitik surplus men-supply kebutuhan ke titiktitik defisit. 


\section{Pendekatan Pemodelan Angkutan Penumpang}

Pendekatan tradisionil dari pemodelan transportasi dikenal dengan Model Empat Tahap Berurutan (The Sequential Demand Model). Pendekatan ini meliputi tahapan antara lain: bangkitan perjalanan, distribusi perjalanaan, pemilihan moda dan pembebanan lalu lintas.

Tahapan model tersebut sejak diperkenalkan melalui studi di Amerika Serikat (Detroit, Chicago) tahun 1950-an banyak diterapkan untuk analisis transportasi perkotaan. Penerapan model ini kebanyakan dilakukan secara berurutan dan keluaran dari sub model pertama merupakan masukan bagi sub model berikutnya.

Alternatif lain pendekatan pemodelan transportasi adalah pemodelan simultan dimana tahap-tahap (sub model-sub model) di atas digabungkan dalam satu model. Model simultan secara tidak langsung menggambarkan suatu keseimbangan pada tujuan perjalanan, moda dan rute dalam jaringan transportasi. Model simultan memberikan prediksi perjalanan di antara sepasang asal tujuan dengan menggunakan moda tertentu dan rute tertentu. Model ini sering digunakan pada studi transportasi antar kota (yaitu Quandt dan Baumol, 1996; Mclynn dan Woronka, 1969; Monsod, 1966, 1967), tetapi jarang dipakai untuk studi transportasi perkotaan (Kraft dan Wohl, 1967).

Model simultan pada dasarnya memasukkan tiga sub model, yang memperkirakan jumlah perjalanan diantara sepasang zona yang menggunakan moda yang ada tanpa memperhatikan rute yang dipilih. Pendekatan ini secara implisit berasumsi bahwa setiap pasang zona asaltujuan hanya terdapat satu rute untuk setiap moda. Asumsi ini sangat realistis untuk diterapkan pada transportasi antar kota karena di antara daerah-daerah perkotaan yang terletak relatif berjauhan satu dengan yang lain jarang tersedia lebih dari satu rute untuk setiap moda yang beroperasi.

\section{Model Permintaan Langsung (Direct Demand Model)}

Menurut Ortuzar dan Willumsen (1994), model permintaan langsung menghitung secara bersama trip generation, trip distribution, dan modal split. Model permintaan langsung berkaitan erat dengan model permintaan ekonometrik. Model langsung terdiri dari 2 tipe, yaitu:

- Murni langsung, menggunakan satu persamaan estimasi tunggal untuk menghubungkan permintaan langsung secara langsung dengan moda, perjalanan dan atribut perorangan.

- Quasi Direct Approach, mengembangkan bentuk terpisah antara modal split dan total (O-D) permintaan transportasi.

Senada dengan Ortuzar, Oppenheim (1995) mengemukakan bahwa bentuk persamaan langsung pada dasarnya regresi statistik linear atau quasi linear (linear or quasi linear regresion statistic). Kelemahan dari model permintaan langsung (direct demand model) yang diungkapkan dengan 
model sintetis adalah kenyataan bahwa model itu sangat deskriptif. Kelemahan secara praktis adalah jumlah variabel yang banyak, bentuk yang multiplikatif dan data yang dibutuhkan. Di sisi lain model permintaan langsung dapat dikalibrasi dalam tampilan yang mudah dibaca. Menurut Papacostas dan Prevedouros (1993) rumus simultan atau langsung (simultanaous or direct formulation) menggambarkan hubungan permintaan perjalanan berdasarkan anggapan bahwa seseorang membuat pilihan perjalanan bersama-sama daripada terpisah-pisah, dan bahwa model permintaan harus dikalibrasi untuk menggambarkan perilaku ini.

Menurut Ortuzar dan Willumsen (1994) suatu bentuk model permintaan langsung yang paling berpengaruh dikemukakan oleh Quant \& Boumel (1966) yang berbentuk abstrack mode demand model.

Ketergantungan pada moda terbaik untuk moda split dan rintangan yang umum adalah kelemahan pendekatan ini. Menurut Crow et all (1973) hal ini dapat dihilangkan dengan menggunakan rata-rata geometrik antar moda menggantikan moda terbaik.

Sedangkan Papacostas

mengemukakan rumus Quant \& Boumol tersebut berbentuk sebagai berikut:

$Q_{i j k}=a_{0}\left(P_{i}\right)^{a 1}\left(P_{j}\right)^{a 2}\left(C_{i j}\right)^{a 3}\left(\frac{C_{i j k}}{C_{i j}}\right)^{a 4}\left(H_{i j}\right)^{a s}\left(\frac{H_{i j k}}{H_{i j}}\right)^{a 6}\left(\frac{D_{i j k}}{D_{i j}}\right)^{a 7}\left(Y_{i j}\right)^{a 8}$

Dimana:

$\mathrm{Q}_{\mathrm{ijk}}$ : aliran perjalanan antara kota $\mathrm{i}$ dan $\mathrm{j}$ dengan moda $\mathrm{k}$

$\mathrm{P}_{\mathrm{i}}, \mathrm{P}_{\mathrm{j}}$ : populasi kota $\mathrm{i}$ dan $\mathrm{j}$

$\mathrm{C}_{\mathrm{ij}}{ }^{*}$ : ongkos minimal perjalanan antara $\mathrm{i}$ dan $\mathrm{j}$

$\mathrm{C}_{\mathrm{ijk}}$ : ongkos dengan moda $\mathrm{k}$
$\mathrm{H}_{\mathrm{ij}}{ }^{*} \quad$ : waktu terpendek perjalanan antara $\mathrm{i}$ dan $\mathrm{j}$

$\mathrm{H}_{\mathrm{ijk}} \quad$ : waktu perjalanan dengan moda $\mathrm{k}$

$\mathrm{D}_{\mathrm{ij}}{ }^{*}$ : jumlah keberangkatan dengan moda $\mathrm{k}$ yang terbanyak frekuensinya

$\mathrm{D}_{\mathrm{ijk}} \quad$ : jumlah frekuensi keberangkatan moda $\mathrm{k}$

$\mathrm{Y}_{\mathrm{ij}} \quad$ : rata-rata pendapatan kota $\mathrm{i}$ dan $\mathrm{j}$

a0...a8 : parameter kalibrasi

Morlok (1988) mengemukakan fungsi permintaan dalam bentuk yang berbeda:

$d_{i j}^{p m}=D^{p m}\left(S_{i}, S_{j}, C_{i j}^{m}, C_{i j}^{n}, \ldots S_{k}, C_{i k}^{m}, C_{i k}^{n}, . . ..\right)$

Dimana:

$\mathrm{d}_{\mathrm{ij}}^{\mathrm{pm}}$ : kuantitas permintaan untuk perjalanan dari kota i ke j untuk melaksanakan maksud $\mathrm{p}$ dengan moda $\mathrm{m}$

$\mathrm{D}^{\mathrm{pm}}$ : fungsi untuk memperkirakan permintaan

$\mathrm{Si}$ : karakteristik sosial ekonomi kota $\mathrm{i}$

$\mathrm{C}_{\mathrm{ij}}^{\mathrm{m}}$ : karakteristik harga \& tingkat pelayanan dengan moda $m$ dari kota $\mathrm{i}$ ke $\mathrm{j}$

$\mathrm{k} \quad$ : kota tujuan alternatif di mana maksud $\mathrm{p}$ mungkin dapat juga dipenuhi.

$\mathrm{n} \quad$ : alternatif terhadap moda $\mathrm{m}$

Morlok mengemukakan alasan dimasukkannya variabel-variabel penjelas tersebut. Karakteristik moda dimasukkan karena tarif dan tingkat pelayanan akan mempengaruhi penggunaan moda yang dikehendaki. Tarif dan tingkat pelayanan dimasukkan karena orang mempertimbangkan hal tersebut untuk melakukan perjalanan. Karakteristik sosio ekonomi dimasukkan karena hakekat permintaan transportasi sebagai permintaan turunan. Selanjutnya Morlok juga mengungkap model fungsi permintaan yang dikemukakan oleh Kraft-SARC (System Analysis and Research Corporation). Model 
ini digunakan untuk memperkirakan jumlah pelaku perjalanan per tahun untuk setiap moda perjalanan: pesawat udara, bus, KA, mobil. Model ini didesain untuk kondisi karakteristik moda mungkin berubah akibat berbagai peningkatan sistem transportasi dan perubahan ongkos perjalanan (waktu dan harga). Model ini berlaku untuk perjalanan dari pintu ke pintu, bukan antar terminal, karena penumpang hanya akan terpengaruh oleh waktu perjalanan total, bukan oleh salah satu komponen biaya atau waktu. Variabel lain yang bisa dimasukkan adalah tingkat kenyamanan, perhitungan untuk masa depan seperti pertambahan penduduk, pekerjaan, penghasilan dan sebagainya. Karena motivasi perjalanan untuk bisnis berbeda dengan lainnya, maka dibuat dua model: model untuk perjalanan bisnis dan perjalanan pribadi.

Menurut Ortuzar \& Willumsen (1994), model yang dikemukakan Kraft-SARC (1968) tersebut berbentuk sebagai berikut:

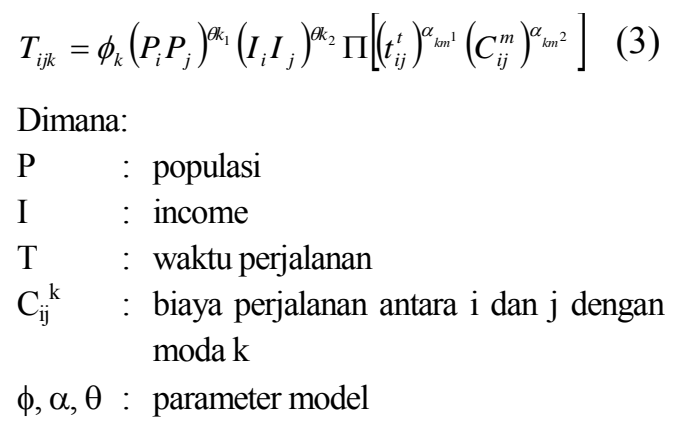

Model yang kompleks ini selanjutnya disederhanakan oleh Manheim pada tahun 1979, dengan melakukan transformasi parameter. Transformasi ini memudahkan interpretasi parameter model. Model yang dikembangkan ini sangat menarik karena dapat merangkum Trip Generation, Trip
Distribution, dan Modal Split secara bersama, termasuk atribut moda kompetisi dan jangkauan pada tingkat pelayanan dan variabel aktivitas. Masalahnya adalah jumlah parameter yang besar yang dibutuhkan untuk mencapai hal ini.

Bentuk alternatif diusulkan oleh Domencich, et al (1968) yang memuat bentuk-bentuk persamaan linear dan eksponensial dalam bentuk multiplikatif.

\section{Sementara itu Oppenheim (1995)} mengungkapkan bentuk persamaan:

$$
T_{i j m r}=\alpha_{i j m r} \Pi X_{j m r}^{k} \beta_{j n r r}^{k} \quad ; \forall i, j, m, r
$$

Tanda $\alpha_{\text {ijmr }}$ dan $\beta_{\text {jmr }}^{\mathrm{k}}$ adalah parameter untuk kalibrasi. Tanda $\alpha_{\mathrm{ijm}}$ mengukur berbagai atribut permintaan seperti zona, tujuan, moda dan rute. Keuntungannya adalah $\beta^{k}$ merupakan ukuran elastisitas permintaan dari $\mathrm{T}_{\mathrm{ijmr}}$ dengan pengaruh dari $\mathrm{X}^{\mathrm{k}}$.

Model lain dari fungsi permintaan langsung yang diusulkan untuk North East Corridor Study of the USA adalah McLynn Model yang berbentuk:

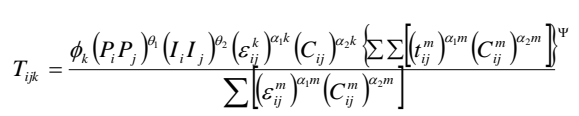

Nilai $\psi$ menurut penelitian McLynn \& Woronka (1969) sebesar 0,7. Angka itu mewakili potensi total perjalanan dari berbagai moda, sehingga model tersebut dapat mencakup modal split dalam perjalanan antar berbagai moda.

Menurut Ortuzar \& Willumsen (1994) satu keuntungan dari model-model di atas adalah dapat membuat model lengkap dari suatu moda baru tanpa mengulangi lagi 
spesifikasinya. Banyak variasi yang berbeda dari model permintaan langsung dicoba dengan dasar mencari sendiri bentuk yang cocok. Hal ini digunakan terutama dalam konteks antar kota dengan sedikit aplikasi dalam wilayah kota. Model permintaan langsung adalah menarik terutama dalam wilayah zona yang besar, contohnya studi antar kota. Timberlake (1988) membahas kegunaan model permintaan langsung di negara berkembang dan menemukan hasil yang lebih baik dibanding pendekatan konvensional.

\section{METODE PENELITIAN}

Prosedur analisis pengembangan model yang dilakukan dalam penelitian ini dari tahapan pemilihan variabel sampai dengan pemilihan model dan validasi dari model yang dihasilkan, mengikuti tahapan-tahapan sebagai berikut:

\section{Pemilihan Variabel}

Pemilihan variabel, khususnya variabel bebas (prediktor) dipilih atas dasar kriteria sebagai berikut:

a. Variabel mempunyai hubungan kausal yang logis dan kuat terhadap volume lalu lintas angkutan penumpang (variabel tak bebas).

b. Variabel secara umum predictable (dapat diramalkan).

c. Variabel secara umum dekat dan sering digunakan dalam penelitian sejenis yang telah teruji. d. Variabel harus dapat memberikan informasi statistik yang signifikan terhadap model.

e. Variabel tidak memiliki hubungan multikolinear.

\section{Pemilihan Variabel Model}

Uji korelasi merupakan pengujian hubungan antar variabel, baik antara variabel bebas dengan variabel tidak bebas maupun antar variabel bebas. Pengujian tersebut untuk mengamati hal-hal sebagai berikut :

a. Apakah terdapat hubungan statistik antara variabel bebas dengan variabel tak bebasnya.

b. Apakah ada persoalan multikolinear antar pasangan variabel bebas.

Dari uji korelasi tersebut diperoleh gambaran variabel bebas mana yang memiliki hubungan kuat atau lemah terhadap variabel tak bebasnya, dan antar variabel bebas mana yang memiliki atau tidak hubungan multikolinear. Hasil uji korelasi inilah yang digunakan sebagai tolok ukur untuk menseleksi variabel bebas mana yang akan digunakan bersamaan, digunakan tidak bersamaan, atau bahkan yang tidak digunakan dalam model.

\section{Pengembangan Model Alternatif}

Dari hasil seleksi variabel di atas dapat dirumuskan beberapa alternatif model dengan berbagai variasi komposisi variabel bebas yang digunakan dengan alternatif model yang dikembangkan adalah model moda-spesifik (moda jalan). 


\section{Kalibrasi Model}

Dari beberapa alternatif model tersebut, dilakukan kalibrasi dengan metoda yang telah dibahas sebelumnya. Kalibrasi terhadap masing-masing alternatif model memberikan hasil : besaran parameter model, koefisien determinasi $\left(\mathrm{R}^{2}\right)$, nilai $\mathrm{t}$ (dari uji-t), dan nilai $\mathrm{F}$ (dari uji-F). Persamaan terbaik tersebut adalah yang mempunyai hasil uji statistik dan uji kesesuaian (goodness of fit) terbaik.

\section{Pengujian Model}

Dari hasil kalibrasi dapat dilakukan penilaian terhadap masing-masing alternatif model yang dikembangkan dengan melihat besaran nilai uji statistik $R^{2}$, $t$, dan $F$, serta tanda aljabar dari parameter model yang dihasilkan. Selanjutnya dipilih beberapa model yang paling memenuhi syarat atas dasar kriteria statistic.

\section{Pemilihan Model}

Model akhir yang dipilih dari alternatif model yang memenuhi syarat tersebut, adalah model yang memiliki nilai $\mathrm{R}^{2}$ terbesar, uji t, uji $\mathrm{F}$ yang sesuai dan tanda aljabar dari parameter model yang sesuai menurut kriteria uji kemasuk-akalan.

\section{Validasi Model}

Validasi model merupakan langkah untuk menilai keandalan model, seberapa baik (sesuai) model kebutuhan transportasi penumpang yang dihasilkan terhadap data yang diamati. Jadi merupakan proses pembandingan hasil model dengan kondisi sesungguhnya.

\section{Wilayah Studi dan Data}

Sebagaimana telah dijelaskan sebelumnya, pengembangan model permintaan langsung ini dilakukan pada wilayah studi di Propinsi Jawa Barat dengan data asal tujuan perjalanan menggunakan hasil survai nasional (ATTN) 2011 dengan melakukan penyesuaian untuk tahun dasar analisis 2014. Adapun data-data bekaitan dengan jarak antar kabupaten dan biaya ekonomi di Jawwa Barat menggunakan data sosio ekonomi Propinsi Jawa Barat.

\section{HASIL DAN PEMBAHASAN}

\section{Asumsi}

Pada dasarnya, model simultan mencakup semua tahapan dalam proses perencanaan transportasi, yang meliputi 4 tahapan pemodelan, yaitu analisis trip generation, trip distribution, modal split dan trip assignment.

Pada penelitian ini, data pergerakan penumpang yang tersedia yaitu dalam moda tertentu yaitu moda jalan, dengan jenis bus dan kendaraan pribadi. Dengan demikian, analisis pemilihan moda pada penelitian ini dengan sendirinya tereliminasi. Selanjutnya, asumsi yang diambil pada penelitian ini adalah hanya satu rute tertentu yang menghubungkan tiap zona pengamatan (yang diwakili oleh jarak antar zona), sehingga analisis pemilihan rute juga akhirnya dieliminasi. Jadi, berdasarkan asumsi yang sudah ditetapkan diatas, pada dasarnya model akhir yang dihasilkan pada penelitian ini hanya mencakup trip generation dan trip 
distribution secara simultan.

Selanjutnya, sebagai variabel tak bebas adalah volume total pergerakan penumpang dari zona $\mathrm{i}$ ke zona $\mathrm{j}$ untuk setiap pasangan zona dengan menggunakan moda jalan m, yang dinotasikan sebagai Tijm. Untuk penelitian ini, diputuskan bahwa pergerakan penumpang yang dimodelkan dibatasi untuk pergerakkan penumpang antara zona kabupaten/kota di Propinsi Jawa Barat.

\section{Penetapan Variabel Model dan Teknik Analisis}

Variabel yang digunakan dalam pemodelan (dengan mempertimbangkan ketersediaan data serta kemudahan prediksinya di masa yang akan dating di Propinsi Jawa Barat) adalah sebagai berikut:

- Jumlah penduduk (orang)

- Produk Domestik Regional Bruto (PDRB) Total (Rp)

- $\mathrm{PDRB} /$ Kapita (Rp/orang)

- Waktu perjalanan (jam)

- Biaya pengangkutan atau Generalized Cost (Rp/penumpang)

- Bangkitan dan Tarikan

Penumpang/Orang (Demand)

Bangkitan dan perjalanan pada kasus ini merupakan variabel tidak bebas, sedangkan variabel-variabel yang lainya merupakan variabel bebas. Diantara variabel tersebut diatas terdapat hubungan kausal. Untuk mengeksekusi variabel-variabel diatas, pada penelitian ini menggunakan teknik analisis regresi. Hasil analisis regresi dapat digunakan untuk memutuskan apakah naik dan turunnya variabel tidak bebas dapat diidentifikasi melalui menaikkan dan menurunkan variabel bebas.

\section{Model Permintaan Langsung}

Berdasarkan uraian variabel model diatas, selanjutnya dapat diidentifikasi satu set kandidat variabel yang dapat menerangkan pergerakan orang/penumpang $\left(\mathrm{T}_{\mathrm{ijm}}\right)$, yaitu : populasi di zona i dan zona $\mathrm{j}(\mathrm{Pi}, \mathrm{Pj})$, PDRB di zona i dan zona j (Gi, Gj), PDRB/kapita (pendapatan) di zona i dan zona $\mathrm{j}(\mathrm{Ki}, \mathrm{Kj})$, Bangkitan di zona i dan tarikan di zona j (Oi, $\mathrm{Dj}$ ), Waktu perjalanan dari zona $\mathrm{i}$ ke zona $\mathrm{j}$ (Wij), Biaya pengangkutan dari zona i ke zona j (Cij).

Pergerakan orang/penumpang $\left(\mathrm{T}_{\mathrm{ijm}}\right)$ dinyatakan sebagai fungsi dari semua variabel yang ditetapkan diatas, yang selanjutnya dinyatakan sebagai:

$$
T_{i j m}=f\left(P_{i}, P_{j}, G_{i}, G_{j}, K_{i}, K_{j}, O_{i}, D_{j}, W_{i j}, C_{i j}\right)
$$

Dimana:

$\begin{aligned} \mathrm{P}_{\mathrm{i}}, \mathrm{P}_{\mathrm{j}}= & \text { populasi di zona } \mathrm{i} \text { dan zona } \mathrm{j} \\ \mathrm{G}_{\mathrm{i}, \mathrm{G}_{\mathrm{j}}=}= & \text { PDRB di zona } \mathrm{i} \text { dan zona } \mathrm{j} \\ \mathrm{K}_{\mathrm{i}}, \mathrm{K}_{\mathrm{j}}= & \text { PDRB/kapita (pendapatan) di zona } \mathrm{i} \\ & \text { dan zona } \mathrm{j} \\ \mathrm{O}_{\mathrm{i}}, \mathrm{D}_{\mathrm{j}}= & \text { Bangkitan di zona } \mathrm{i} \text { dan tarikan di } \\ & \text { zona } \mathrm{j} \\ \mathrm{W}_{\mathrm{ij}}= & \text { Waktu perjalanan dari zona } \mathrm{i} \text { ke zona } \\ & \mathrm{j} \\ \mathrm{C}_{\mathrm{ij}}= & \text { Biaya pengangkutan dari zona } \mathrm{i} \text { ke } \\ & \text { zona } \mathrm{j}\end{aligned}$

Berdasarkan variabel tersebut terdapat 3 (tiga) kelompok alternatif persamaan model, antara lain: i) model yang tersusun atas variabel tunggal, ii). model tersusun atas perkalian antara pasangan variabel asal tujuan, iii) kombinasi dari alternatif (i) dan 
alternatif (ii), tersusun atas variabel tunggal dan/atau perkalian variabel.

Tiap-tiap alternatif tersebut dapat dikembangkan lebih lanjut dan dapat dikalibrasi untuk memperoleh nilai parameternya. Namun pada penelitian ini, hanya kelompok persamaan model alternatif (i), yaitu bentuk dasar model, yang tersusun atas variabel tunggal yang akan dikaji pada penelitian ini. Pertimbangan ini dilakukan dengan dua alasan, yaitu:

- Berdasarkan kajian sebelumnya, kelompok persamaan model (ii) dan (iii) cenderung menunjukkan hasil yang relative tidak signifikan dibandingkan dengan kelompok persamaan model (i).

- Dalam proses estimasinya, kelompok persamaan model (ii) dan (iii) cenderung lebih sulit.

Dalam pemilihan persamaan yang terbaik, dalam hal ini sebagai contoh adalah metode regresi, digunakan prosedur Regresi Stepwise yaitu metode statistik untuk pemilihan variabel bebas yang signifikan di antara 1 (satu) set variabel. Salah satu penilaian dalam pemilihan alternatif persamaan tersebut adalah dengan Kebaikan Suai (goodness of fit) yang paramaternya adalah koefisien determinasi $\left(\mathrm{R}^{2}\right)$. Koefisien determinasi menggambarkan besarnya total variasi yang dapat diterangkan oleh variabel bebas dibandingkan dengan total variasi variabel bebasnya.

Perhitungan korelasi antar variabel bebas dan tak bebas, serta antara masingmasing variabel bebas merupakan langkah awal dalam prosedur regresi stepwise. Korelasi yang memberikan tanda aljabar positif menandakan pola perubahan yang sama antara variabel tinjauan, dan sebaliknya. Makin mendekati nilai 1.0 atau -1.0 , makin baik korelasi antar variabel tinjauan, yang berarti dapat dikatakan variabel tersebut dapat saling menerangkan.

\section{Analisis Korelasi dan Alternatif Model}

\section{Permintaan Langsung}

Alternatif persamaan model pertama merupakan persamaan dengan variabel tunggal dimana persamaan (6) di atas dibuat secara operasional dalam bentuk persamaan regresi non linear (Model Simultan):

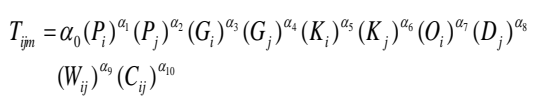

Karena hubungan dari variabel tersebut adalah non linear dan sulit untuk mengkalibrasi parameternya, sehingga variabel tersebut perlu ditransformasikan menggunakan transformasi logaritma dan persamaan regresinya menjadi:

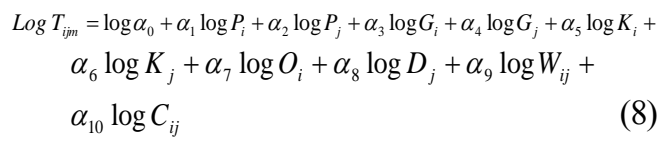

Dalam bentuk linear :

$$
\begin{gathered}
Y=a+b_{1} x_{1}+b_{2} x_{2}+b_{3} x_{3}+b_{3} x_{3}+b_{4} x_{4}+b_{5} x_{5}+ \\
b_{6} x_{6}+b_{7} x_{7}+b_{8} x_{8}+b_{9} x_{9}+b_{10} x_{10}
\end{gathered}
$$

Dimana :

$Y=\log T_{i j m}$

$a=\log \alpha_{0}$

$b_{1} . . b_{10}=\alpha_{1} \ldots \alpha_{10}$

$x_{1}=\log P_{i} ; x_{2}=\log P_{j} ; x_{3}=\log G_{i}$;

$x_{4}=\log G_{j} ; x_{5}=\log K_{i} ; x_{6}=\log K_{j}$; 


$$
\begin{aligned}
& x_{7}=\log O_{i} ; x_{8}=\log D_{j} ; x_{9}=\log W_{i j} ; \\
& x_{10}=\log C_{i j} \text {; } \\
& \mathrm{Y} \quad=\text { variabel tak bebas (independent } \\
& \text { variable) } \\
& x_{1} \ldots x_{10}=\text { variabel bebas (dependent } \\
& \text { variable) }
\end{aligned}
$$

$a, b_{1} \ldots b_{10}=$ konstanta regresi

Perhitungan korelasi menghasilkan matriks korelasi dari 10 (sepuluh) variabel (dalam logaritma) ditunjukkan pada Tabel 1.

Tabel 1. Matriks Korelasi untuk Alternatif Persamaan Model

\begin{tabular}{|c||c|c|c|c|c|c|c|c|c|c|c|}
\hline & $Y$ & $X 1$ & $X 2$ & $X 3$ & $X 4$ & $X 5$ & $X 6$ & $X 7$ & $X 8$ & $X 9$ & $X 10$ \\
\hline \hline$Y$ & 1,000 & & & & & & & & & & \\
\hline$X 1$ & 0,612 & 1,000 & $X$ & & & & & & & & \\
\hline$X 2$ & 0,579 & $-0,040$ & 1,000 & $X$ & & & & & & & \\
\hline$X 3$ & 0,517 & 0,823 & $-0,033$ & 1,000 & $X$ & & & & & & \\
\hline$X 4$ & 0,467 & $-0,033$ & 0,823 & $-0,040$ & 1,000 & $X$ & & & & & \\
\hline$X 5$ & $-0,017$ & $-0,067$ & 0,003 & 0,512 & $-0,020$ & 1,000 & $X$ & & & & \\
\hline$X 6$ & $-0,055$ & 0,003 & $-0,067$ & $-0,020$ & 0,512 & $-0,040$ & 1,000 & $X$ & & & \\
\hline$X 7$ & 0,618 & 0,964 & $-0,039$ & 0,839 & $-0,034$ & 0,016 & 0.000 & 1,000 & & & \\
\hline$X 8$ & 0,590 & $-0,039$ & 0,970 & $-0,033$ & 0,816 & 0,001 & $-0,035$ & $-0,040$ & 1,000 & & \\
\hline$X 9$ & $-0,425$ & 0,003 & 0,001 & $-0,052$ & $-0,056$ & $-0,094$ & $-0,100$ & $-0,034$ & $-0,039$ & 1,000 & \\
\hline$X 10$ & $-0,444$ & $-0,006$ & $-0,008$ & $-0,062$ & $-0,067$ & $-0,099$ & $-0,106$ & $-0,045$ & $-0,052$ & 0,986 & 1,000 \\
\hline
\end{tabular}

Berdasarkan hasil analisis korelasi antar variabel, dapat diamati hal-hal sebagai berikut:

a. Variabel bebas yang mempunyai korelasi (r) yang tinggi (yaitu $\mathrm{r}>0,5$ ) dengan variabel tak bebas adalah X1 (Pi), X2 (Pj), X3 (Gi), X7 (Oi) dan X8 (Dj).

b. Berkaitan dengan masalah multikolinearitas, variabel bebas yang mempunyai korelasi yang tinggi (yaitu $r$ $>0,5)$ dengan variabel bebas yang lain adalah : X1 dengan X3 (Pi dengan Gi) ; $\mathrm{X} 2$ dengan $\mathrm{X} 4(\mathrm{Pj}$ dengan $\mathrm{Gj})$; X3 dengan X5 (Gi dengan Ki); X4 dengan X6 (Gj dengan $\mathrm{Kj})$; X1 dengan X7 (Pi dengan Oi); X3 dengan X7 (Gi dengan Oi); X2 dengan X8 (Pj dengan $\mathrm{Dj}) ; \mathrm{X} 4$ dengan $\mathrm{X} 8$ ( $\mathrm{Gj}$ dengan $\mathrm{Dj})$; dan $\mathrm{X} 9$ dengan X10 (Wij dengan Cij), sehingga

Volume 1, No. 1, Januari 2015 variabel tersebut tidak dapat dimasukkan bersama dalam satu persamaan.

c. Korelasi diantara masing-masing variabel sangat nyata apabila probabilitas jauh di bawah 0.05. Berdasarkan analisis, tingkat signifikansi koefisien korelasi satu sisi yang diukur dari probabilitas menghasilkan angka 0.000 atau praktis 0 .

Kemudian, berdasarkan korelasi antar variabel dari matriks korelasi tersebut diatas dapat diidentifikasi beberapa alternatif persamaan model. Selanjutnya parameter dari setiap alternatif model akan dapat diestimasi atau dikalibrasi. Model permintaan langsung dengan parameter yang sudah dikalibrasi selanjutnya dilakukan evaluasi dengan serangkaian uji statistik untuk memberikan validitas model dalam mengestimasi pada kondisi saat ini dan yang akan datang. 


\section{Kalibrasi Model}

Pada penelitian ini, metode estimasi parameter model yang digunakan adalah metode kuadrat terkecil (least square method), yang diselesaikan dengan cara regresi (linear).
Hasil kalibrasi model untuk model volume pergerakan penumpang dapat dilihat pada Tabel 2. Terdapat 7(tujuh) model yang memenuhi kriteria pemilihan model.

Tabel 2. Uji Statistik Model Alternatif

Coefficients



a. Dependent Variable: JUMLAH PENUMPANG (Y) 
Pada model 2 untuk variabel $\mathrm{X}_{7}$, diperoleh besar tolerance adalah 0.988 . Hal ini berarti $\mathrm{R}^{2}$ adalah $1-0.988$ atau 0.012 . Hal ini berarti hanya $1,2 \%$ variabilitas $\mathrm{X}_{7}$ dapat dijelaskan oleh prediktor (variabel bebas) yang lain. Angka tolerance yang ditetapkan adalah 0,0001 . Semua variabel yang akan dimasukkan dalam perhitungan model regresi harus mempunyai tolerance di atas 0,0001. Terlihat bahwa semua variabel telah memenuhi persyaratan ambang toleransi.

VIF (Variance Inflation Factor) merupakan sebuah factor inflasi dari suatu varians. Pada umumnya, jika VIF lebih besar dari 5, maka variabel tersebut mempunyai persoalan multikolinearitas dengan variabel bebas yang lainnya. Sebagai contoh, hasil regresi menunjukkan bahwa variabel bebas $\mathrm{X}_{9}$ dan $\mathrm{X}_{10}$ mempunyai VIF $>5$, sehingga dapat diduga ada persoalan multikolinearitas. Jadi variabel yang akan dimasukkan dalam persamaan regresi adalah variabel yang mempunyai korelasi terbesar dengan variabel $\mathrm{T}_{\mathrm{ijm}}$ adalah variabel dari $\mathrm{X}_{10}$ yaitu $\mathrm{C}_{\mathrm{ij}}$.

Tabel 3. Hasil Estimasi Parameter Model dari Beberapa Alternatif Persamaan Model

\begin{tabular}{|c|c|c|c|c|c|c|c|c|c|c|}
\hline \multirow{2}{*}{ No. } & \multirow{2}{*}{\begin{tabular}{|c|} 
Variabel \\
Model
\end{tabular}} & \multirow{2}{*}{$\begin{array}{c}\text { Parameter } \\
\text { Model }\end{array}$} & \multirow{2}{*}{ Tanda } & \multicolumn{7}{|c|}{ Model } \\
\hline & & & & 1 & 2 & 3 & 4 & 5 & 6 & 7 \\
\hline \multirow{2}{*}{1} & \multirow{2}{*}{ Konstanta } & \multirow{2}{*}{$\alpha 0 *$} & \multirow{2}{*}{$(+) /(-)$} & 4,438 & 2,968 & 9,013 & 5,725 & 2,492 & 2,961 & 3,407 \\
\hline & & & & 62,616 & 46,441 & 46,832 & 16,387 & 5,451 & 6,618 & 7,406 \\
\hline \multirow{2}{*}{2} & \multirow{2}{*}{$\mathrm{Pi}$} & \multirow{2}{*}{$\alpha 1$} & \multirow{2}{*}{$(+)$} & \multirow{2}{*}{ - } & \multirow{2}{*}{-} & \multirow{2}{*}{ - } & 0,737 & 0,775 & 0,783 & 0,715 \\
\hline & & & & & & & 10,912 & 12,313 & 12,872 & 11,323 \\
\hline \multirow{2}{*}{3} & \multirow{2}{*}{$\mathrm{Pj}$} & \multirow{2}{*}{$\alpha 2$} & \multirow{2}{*}{$(+)$} & \multirow{2}{*}{-} & \multirow{2}{*}{ - } & \multirow{2}{*}{ - } & \multirow{2}{*}{-} & 0,702 & 0,813 & 0,817 \\
\hline & & & & & & & & 10,060 & 11,707 & 11,873 \\
\hline 4 & $\mathrm{Gi}$ & $\alpha 3$ & $(+)$ & - & - & - & - & - & - & - \\
\hline \multirow{2}{*}{5} & \multirow{2}{*}{ Gj } & \multirow{2}{*}{$\alpha 4$} & \multirow{2}{*}{$(+)$} & \multirow{2}{*}{ - } & \multirow{2}{*}{ - } & \multirow{2}{*}{ - } & \multirow{2}{*}{ - } & - & $-0,167$ & $-0,171$ \\
\hline & & & & & & & & 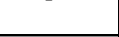 & $-6,767$ & $-6,985$ \\
\hline 6 & $\mathrm{Ki}$ & $\alpha 5$ & $(+)$ & - & - & - & - & - & - & $-0,092$ \\
\hline & & & & & & & & & & $-3,625$ \\
\hline 7 & Kj & $\alpha 6$ & $(+)$ & - & - & - & - & - & - & - \\
\hline 8 & 0 i & 7 & $(+1)$ & 0,99 & 1,029 & 0,999 & 0,297 & 0,259 & 0,25 & 0,316 \\
\hline 8 & U & $\alpha /$ & $(+)$ & 19,988 & 33,256 & 51,958 & 4,446 & 4,166 & 4,161 & 5,072 \\
\hline 0 & $\mathrm{Di}$ & 88 & $(+1)$ & 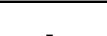 & 1,012 & 0,978 & 0,977 & 0,285 & 0,335 & 0,335 \\
\hline 9 & D] & $\alpha \delta$ & $(+)$ & - & 31,874 & 49,513 & 53,792 & 4,016 & 4,863 & 4,906 \\
\hline 10 & Wij & $\alpha 9$ & $(-)$ & - & - & - & - & - & - & - \\
\hline & & & & 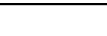 & 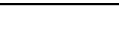 & $-1,202$ & $-1,255$ & $-1,315$ & $-1,334$ & $-1,341$ \\
\hline 11 & Cij & $\alpha 10$ & $(-)$ & - & - & $-32,101$ & $-36,100$ & $-39,983$ & $-41,786$ & $-42,322$ \\
\hline & & & & & & & & & & \\
\hline & & $R^{2}$ & & 0,381 & 0,759 & 0,907 & 0,922 & 0,932 & 0,937 & 0,938 \\
\hline & & F-Stat & & 399,51 & $1.020,61$ & $2.106,53$ & $1.898,45$ & $1.774,97$ & $1.589,64$ & $1.390,15$ \\
\hline
\end{tabular}

Analisis dari alternatif persamaan model tersebut adalah sebagai berikut :

a. Untuk alternatif model 1 sampai 5, tanda untuk tiap-tiap parameter telah sesuai dengan yang diharapkan. Sedangkan untuk model 6 dan 7 , terdapat tanda parameter model yang tidak sesuai, yaitu untuk PDRB dan Pendapatan per Kapita. Dalam hal ini dapat diketahui bahwa, walaupun indicator koefisien nya tinggi, namun masih ada variabel yang masih 
mengandung multikolinear dan dengan tanda yang tidak sesuai, yang berarti bahwa model ini dapat diabaikan.

b. Signifikansi statistik dievaluasi sebagai berikut :

- Nilai F persamaan model 1 sampai 7 melewati nilai kritis pada tingkat kepercayaan 95\% dengan tingkat signifikansi 0.00 . Oleh karena probabilitas (0.00) jauh lebih kecil kecil dari 0.05 , maka model regresi dapat dipakai untuk memprediksi $\mathrm{T}_{\mathrm{ijm}}$.

- Semua variabel model mempunyai nilai $t$ yang lebih besar dari 1.645 yang merupakan nilai $\mathrm{t}$ kritis (dihitung dari $t$ tabel).

- Semua model mempunyai nilai $\mathrm{R}^{2}$ antara $0,381-0.938$.

- Nilai $\mathrm{R}^{2}$ yang tertinggi dari model alternatif I adalah model 7 sebesar 0.938 , yang berarti $93.8 \%$ dari variansi variabel tak bebas dapat diterangkan dengan model $(93.8 \%$ volume pergerakan penumpang dapat diterangkan oleh populasi di zona $\mathrm{i}$ dan zona $\mathrm{j}$, PDRB zona tujuan, pendapatan per kapita zona asal, bangkitan zona asa dan tarikan zona tujuan, dan biaya pengangkutan).

Dari analisis di atas, persamaan model yang dapat dipilih berdasarkan nilai $\mathrm{R}^{2}$ tertinggi adalah persamaan model 7. Namun berdasarkan kriteria uji tanda, persamaan ini dan persamaan model 6 tidak memenuhi syarat, dengan demikian persamaan yang terpilih adalah persamaan model 5 (persamaan 10), yang mempunyai nilai $\mathrm{R}^{2}$ tertinggi setelah model 6 dan 7 dan tanda parameter yang sesuai secara signifikan.

$$
T_{i j m}=10^{2,492}\left(P_{i}\right)^{0,775}\left(P_{j}\right)^{0,702} \cdot\left(O_{i}\right)^{0,259} \cdot\left(D_{j}\right)^{0,285} \cdot\left(C_{i j}\right)^{-1,315}
$$

Model akhir diatas mempunyai arti:

\ Bahwa volume pergerakan penumpang dari zona asal ke zona tujuan dipengaruhi oleh variabel populasi di zona asal dan tujuan, bangkitan di zona asal, tarikan di zona tujuan dan biaya pengangkutan dari zona asal ke zona tujuan;

a Konstanta sebesar $10^{2,492}$ menyatakan, bahwa jika tidak ada populasi di zona asal dan tujuan, bangkitan di zona asal, tarikan di zona tujuan dan biaya pengangkutan dari zona asal ke zona tujuan, maka volume pergerakan penumpang sebesar $10^{2,492}$;

口 Parameter $\mathrm{P}_{\mathrm{i}} \quad$ sebesar 0,775 menyatakan bahwa setiap penambahan 1 orang penduduk total zona asal akan merubah volume pergerakan penumpang sebesar pangkat 0.775 dari satuan $\mathrm{P}_{\mathrm{i}}$;

$\begin{array}{llll} & \text { Parameter } \mathrm{P}_{\mathrm{j}} \quad \text { sebesar } & 0,702\end{array}$ menyatakan bahwa setiap penambahan 1 orang penduduk total zona tujuan akan merubah volume pergerakan penumpang sebesar pangkat 0,702 dari satu satuan $\mathrm{P}_{\mathrm{j}}$;

口 Parameter $\mathrm{O}_{\mathrm{i}}$ sebesar 0,259 menyatakan bahwa setiap penambahan 
1 bangkitan perjalanan di zona asal akan merubah volume pergerakan penumpang sebesar pangkat 0.259 dari satuan $\mathrm{O}_{i}$;

口 Parameter $\mathrm{D}_{\mathrm{j}}$ sebesar 0,285 menyatakan bahwa setiap penambahan 1 tarikan perjalanan di zona tujuan akan merubah volume pergerakan penumpang sebesar pangkat 0.285 dari satuan $\mathrm{D}_{\mathrm{j}}$;

口 Parameter $\mathrm{C}_{\mathrm{ij}}$ sebesar $-1,315$ menyatakan bahwa setiap penambahan Rp 1,- biaya pengangkutan dari zona asal ke zona tujuan akan mengurangi volume pergerakan penumpang sebesar pangkat $-1,315$ dari satuan $\mathrm{C}_{\mathrm{ij}}$.

\section{Validasi Model}

Pada penelitian ini, penulis melakukan validasi model dengan $\mathrm{R}^{2}$ dan Chi Square.

Pada pengujian dengan $\mathrm{R}^{2}$ disyaratkan bahwa koefisien determinasi linear antara $T_{\mathrm{ijm}}$ hasil pemodelan dengan hasil observasi harus diatas 0,5. Berdasarkan hasil pengolahan data sebagaimana terlihat pada Gambar 1 dapat diketahui bahwa koefisiens determinasi $\left(\mathrm{R}^{2}\right)$ antara hasil model dengan hasil observasi adalah 0,778. Hal ini menunjukkan bahwa model yang dihasilkan adalah valid dan dapat digunakan untuk melakukan estimasi matriks perjalanan $\left(\mathrm{T}_{\mathrm{ijm}}\right)$ pada masa yang akan datang.

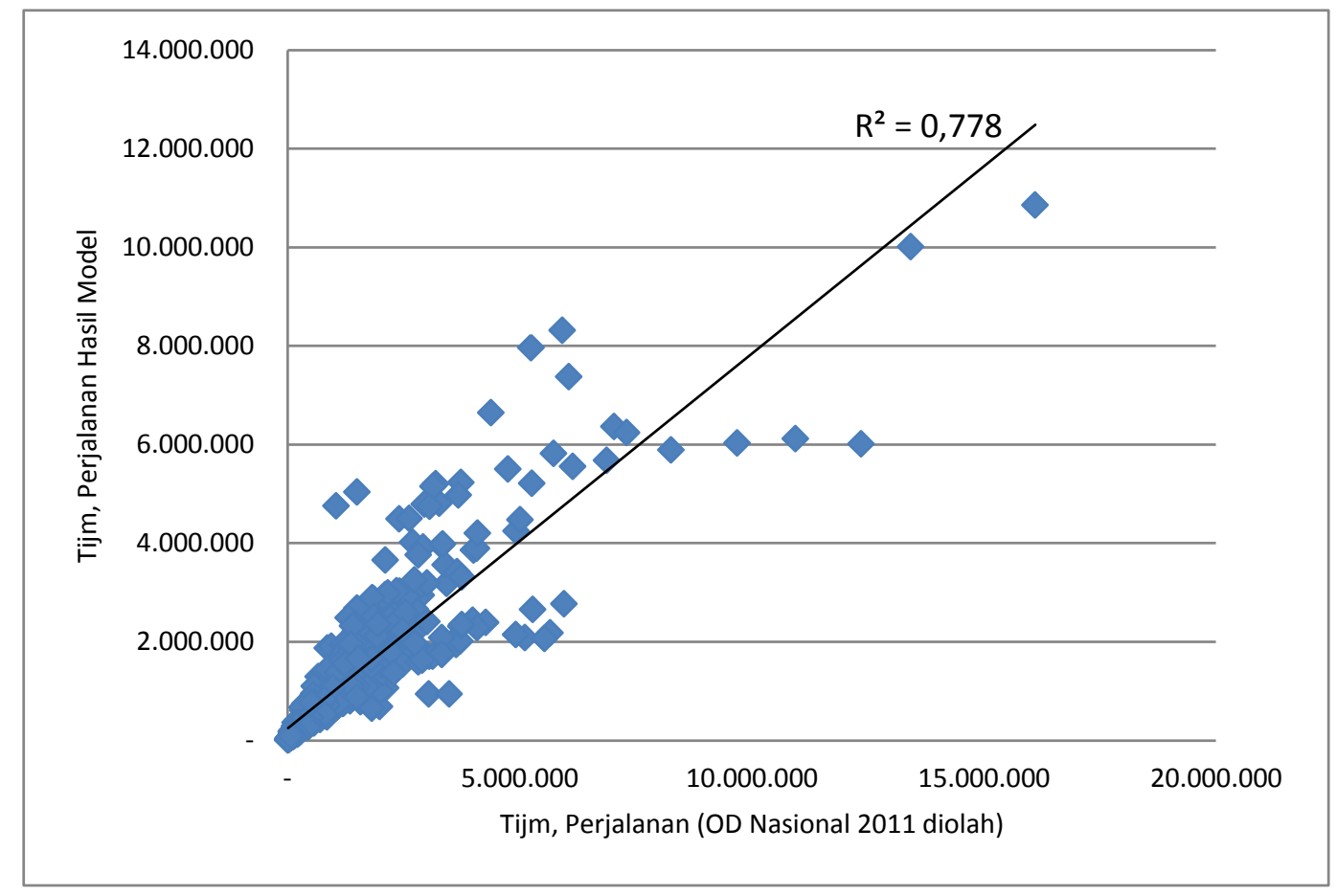

Gambar 1. Validasi Model

Volume 1, No. 1, Januari 2015 
Dan berdasarkan hasil tes Chi Square $\left(\mathrm{X}^{2}\right)$ diperoleh :

- Chi Square $\left(\mathrm{X}^{2}\right)$ hasil perhitungan $=12,253$, dan

- Chi Square menurut tabel, $\mathrm{X}^{2}{ }_{0.05(650)}=662,332$

Dengan demikian $\mathrm{X}^{2}$ tabel $>\mathrm{X}^{2}$ hitung, hal ini berarti bahwa $\mathrm{H}_{0}$ dapat diterima, dengan demikian, kesimpulan yang diambil adalah $\mathrm{T}_{\mathrm{ijm}}$ hasil survai $\left(\mathrm{O}_{\mathrm{i}}\right)$ sama dengan $\mathrm{T}_{\mathrm{ijm}}$ hasil model $\left(\mathrm{E}_{\mathrm{i}}\right)$.

\section{Sensitifitas Model}

Untuk mengetahui pengaruh perubahan salah satu variabel bebas terhadap variabel tak bebas perlu dilakukan analisis sensitivitas. Analisis sensitivitas dilakukan dengan merubah-ubah nilai salah satu variabel (seperti populasi zona asal, populasi zona tujuan, bangkitan perjalanan zona asal, tarikan zona tujuan dan biaya pengangkutan) sedangkan variabel yang lain konstan.

Hasil analisis sensitivitas model dapat ditunjukkan dengan grafik sebagaimana pada Gambar 2, dimana sumbu vertikal adalah volume pergerakan penumpang (dalam persentase perubahan) dan sumbu horizontal adalah variabel yang diamati yaitu populasi zona asal dan tujuan, bangkitan dan tarikan perjalanan, dan biaya pengangkutan. Grafik perubahan tiap variabel mempunyai bentuk yang sama untuk semua pergerakan di zona studi kecuali grafik untuk biaya pengangkutan.

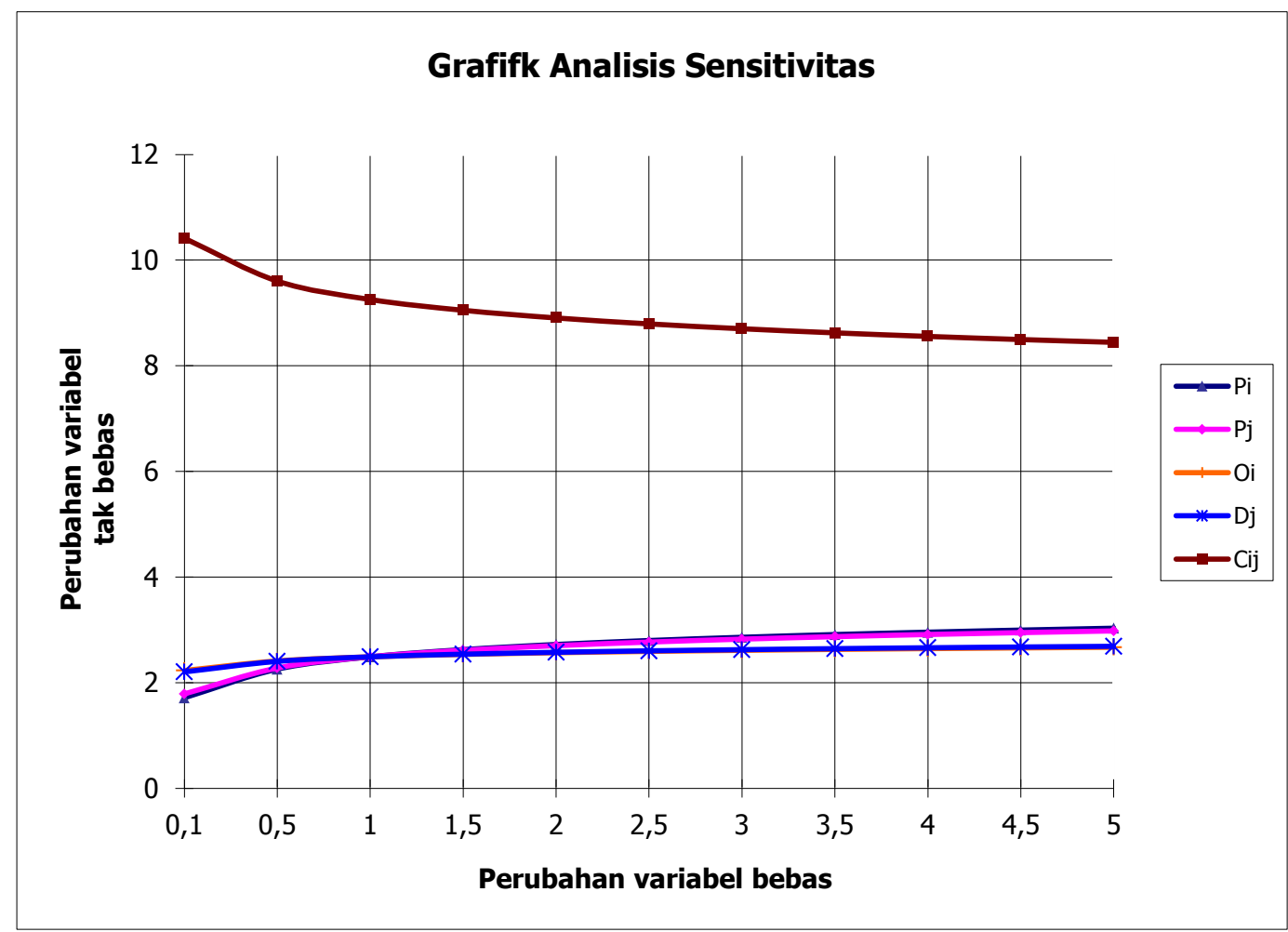

Gambar 2. Sensitifitas Model terhadap Perubahan Nilai Variabel Bebas 
Berdasarkan grafik analisis sensitivitas diatas terlihat bahwa kurva variabel biaya pengangkutan lebih lengkung dan berpisah jauh dengan variabel yang lainnya, sehingga dapat dikatakan perubahan biaya pergerakan penumpang lebih sensitif, artinya penurunan biaya pengangkutan akan menyebabkan naiknya volume pergerakan penumpang relatif cepat ( $\Delta$ perubahan $\gg>$ ). Sedangkan kurva populasi zona asal dan tujuan relatif linear (positif) dimana perubahan volume pergerakan penumpang sangat proporsional dengan variabel tersebut. Kondisi ini juga ditunjukkan oleh kurva Bangkitan Zona Asal $\left(\mathrm{O}_{\mathrm{i}}\right)$ dan Tarikan Zona Tujuan $\left(\mathrm{D}_{\mathrm{j}}\right)$.

\section{KESIMPULAN DAN SARAN}

\section{Kesimpulan}

- Model yang terpilih telah memenuhi kriteria $\mathrm{R}^{2}$ yang terbesar dan memenuhi tanda aljabar untuk setiap variabelnya, yaitu:

$$
T_{i j m}=10^{2,492}\left(P_{i}\right)^{0,775}\left(P_{j}\right)^{0,702} \cdot\left(O_{i}\right)^{0,259} \cdot\left(D_{j}\right)^{0,285} \cdot\left(C_{i j}\right)^{-1,315}
$$

Model permintaan langsung angkutan penumpang di Propinsi Jawa Barat diatas dipengaruhi oleh populasi zona asal dan tujuan, bangkitan perjalanan zona asal dan tarikan perjalanan zona tujuan dan biaya perjalanan dari asal ke tujuan.

- Variabel yang signifikan menerangkan kebutuhan pergerakan angkutan penumpang regional di Propinsi Jawa Barat adalah populasi zona asal dan tujuan, bangkitan perjalanan zona asal dan tarikan perjalanan zona tujuan dan biaya perjalanan dari asal ke tujuan.

- Variabel yang paling sensitif terhadap model yang diperoleh adalah biaya pengangkutan, yang berarti pengurangan biaya pengangkutan akan mengakibatkan kenaikan volume pergerakan penumpang yang relatif besar.

\section{Saran}

Beberapa hal yang perlu mendapat perhatian lebih untuk penelitian selanjutnya, yaitu:

- Lingkup studi dapat dikembangkan untuk pergerakan dari/ke daerah luar propinsi kajian dengan alternative model lainnya.

- Model dapat dikembangkan untuk transportasi multi moda, dengan lebih dari satu rute yang menghubungkan antara setiap pasangan zona, dengan data yang lebih komprehensif dan penggunaan variabel lain yang belum dibahas dalam penelitian ini.

- Aplikasi model untuk prediksi volume pergerakan penumpang pada masa yang akan datang sebaiknya mempertimbangkan batasan model yang merupakan konsekuensi dari asumsi yang diambil dalam pengembangan model, struktur model, dan data yang tersedia untuk mengkalibrasi model. 
DAFTAR PUSTAKA

Departemen Pekerjaan Umum, 2004. Studi Updating Biaya Operasi Kendaraan dan Nilai Waktu untuk Masukan Model RUCM IRMS

Ibrahim dan N. Sudjana, 2005. Penelitian dan Penilaian Pendidikan. Bandung: Sinar Baru.

Julianti, I., 2003. Pemodelan Permintaan Langsung (Direct Demand Model) Angkutan Penumpang Antar Kabupaten di Propinsi Jawa Tengah.

Jansson, K., dan Mortazavi, R., 2000. Handbook of Transport Modelling, Vol 1; New York: Pergamon.

Kanafani, A.,1983. Transportation Demand Analysis. New York: Mc Graw-Hill.

Lee, C., Models in Planning - An Introduction to the Use of Quantitative Models in Planning. New York: Pergamon Press.

Ortuzar, J.D., and Willumsen, L.G., 1994.
Modelling Transport, Third Edition, Chichester: John Wiley\&Sons.

Rutherford, G.S., 1977. An Introduction to Urban Travel Demand Forecasting. User-Oriented Materials for UTPS: Federal Highway Administration.

Santoso, S., 2013. SPSS Versi 12. Jakarta: PT Elex Media Komputindo.

Sjafruddin, A., 1992. Intercity Transport in Indonesia, Passenger Travel Demand Modelling. Report No.67, Institute of Roads, Transport \& Town Planning, Technical University of Denmark.

Sudjana, 1988. Metoda Statistika. Bandung: Tarsito.

Sugiyono, 2007. Statistik Untuk Penelitian, Edisi Kedua Belas. Bandung: Alfabeta.

Tamin, O.Z.,2000. Perencanaan dan Pemodelan Transportasi, Edisi Ketiga. Bandung: Institut Teknologi Bandung. 